CLINICAL STUDY

\title{
Pediatric renal allograft transplantation does not normalize the increased cortisol/cortisone ratios of chronic renal failure
}

\author{
Michael Schroth, Christian Plank, Manfred Rauh, Helmuth-Günther Dörr, Wolfgang Rascher and Jörg Dötsch \\ Department of Pediatrics, Friedrich-Alexander-University Erlangen-Nürnberg, Loschgestraße 15, D-91054 Erlangen, Germany
}

(Correspondence should be addressed to M Schroth, Kinder-und Jugendklinik, Universitätsklinikum Erlangen, Loschgestraße 15, D-91054 Erlangen, Germany; Email: michael_schroth@yahoo.de)

\begin{abstract}
Objective: The conversion of cortisol (F) to cortisone (E) is catalyzed by 11 beta-hydroxysteroid dehydrogenase type 2 (11 $\beta$-HSD2). Children suffering from chronic renal failure (CRF) have a decreased activity of $11 \beta$-HSD2 contributing to increased arterial blood pressure. The objective was to investigate whether a normal conversion of $\mathrm{F}$ to $\mathrm{E}$ is achieved after renal transplantation (TX) in children. Methods: Fifteen children with CRF, 17 children with steroid-free immunosuppression after TX, and 18 healthy controls (CO) were enrolled. The activity of 11ß-HSD2 in plasma was calculated using the ratio of $\mathrm{F} / \mathrm{E}$ determined by tandem mass spectrometry, the ratio of tetrahydrocortisol (THF) $+5 \alpha$-tetrahydrocortisol $(5 \alpha \mathrm{THF})$ in urine determined by gas chromatography/mass spectrometry, and the ratio of (THF $+5 \alpha \mathrm{THF}) /$ tetrahydrocortisone (THE) in urine determined by tandem mass spectrometry.

Results: The F/E ratio (mean \pm S.D./s.E.M.) was significantly higher in CRF and TX $(5.6 \pm 1.9 / 0.6$, $7.12 \pm 3.1 / 0.9)$ than in $\mathrm{CO}(1.18 \pm 0.2 / 0.03, \mathrm{P}<0.0001)$ groups. The (THF $+5 \alpha \mathrm{THF}) / \mathrm{THE}$ ratio in CRF $(1.19 \pm 1.1 / 0.5)$ and TX $(1.19 \pm 0.1 / 0.5)$ groups was significantly higher than in controls $(0.21 \pm 0.05 / 0.18, \quad P<0.0001)$. Positive correlations between plasma and urinary ratios $\left(P=0.0004 . \mathrm{R}^{2}=0.73\right.$ in CRF, $P=0.0013, \mathrm{R}^{2}=0.56$ in TX, $P<0.0001, \mathrm{R}^{2}=0.66$ in $\left.\mathrm{CO}\right)$ were found, whereas significant correlations between F/E or (THF $+5 \alpha \mathrm{THF}$ )/THE ratios and blood pressure, the number of antihypertensive drugs taken or creatinine clearance could not be found. Conclusions: In all children with chronic renal failure plasma and urinary cortisol/cortisone ratios are elevated and do not return to normal levels after renal allograft transplantation. This suggests that renal transplantation does not normalize $11 \beta$-HSD2 activity.
\end{abstract}

European Journal of Endocrinology 154 555-561

\section{Introduction}

The conversion of active cortisol (F) to inactive cortisone (E) is catalyzed by 11 beta hydroxysteroid dehydro-

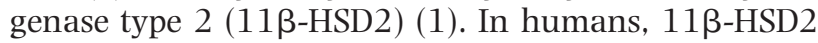
is active in the kidney and placenta $(2-4)$. In the cortical collecting duct, where most of the catalyzation of $\mathrm{F}$ to E takes place, the metabolites of these glucocorticoids, tetrahydrocortisol (THF), 5 $\alpha$-tetrahydrocortisol ( $5 \alpha \mathrm{THF})$ and tetrahydrocortisone (THE), are excreted in urine $(5,6)$. The isoenzyme $11 \beta$-HSD type 1 catalyzes the reverse action from $\mathrm{E}$ to $\mathrm{F}$ in adipose tissue, human lung and liver (4, 7). 11ß-HSD2 dysregulation is involved in arterial hypertension in acquired disorders such as hypercortisolism and primary arterial hypertension $(8,9)$. Absolute $11 \beta$-HSD2 deficiency is the cause of apparent mineralocorticoid excess (AME), a rare autosomal recessive defect due to a mutation in $11 \beta-H S D 2(10,11)$. This syndrome is characterized by sodium retention and hypervolemia despite low plasma renin activity and reduced aldosterone levels. On a physiological base, the regulation of $11 \beta-H S D$ activity is in a certain correlation with changes of arterial blood pressure during childhood $(12,13)$.

In chronic renal failure (CRF) $11 \beta$-HSD 2 activity is reduced (14). Therefore, diminished cortisol inactivation is thought to contribute to arterial hypertension in CRF. Palermo and co-workers report a patient with AME who was cured by kidney transplantation. This case indicates that normalization of $11 \beta-H S D 2$ activity and, consequently, cortisol metabolism after transplantation, is possible (15).

Arterial hypertension is very common in children after renal allograft transplantation $(16,17)$. The reasons are multifactorial, i.e. chronic allograft failure, immunosuppressive therapy and reno-vascular disorders $(16,18-20)$. Detection and therapy of arterial hypertension in these patients remains of great 
importance in order to avoid severe damage to the transplanted kidney $(12,18,21)$.

The possible contribution of reduced $11 \beta-\mathrm{HSD} 2$ activity to elevated blood pressure after renal transplantation has not been investigated. Therefore, the objective of the present study was to examine whether the plasma $\mathrm{F} / \mathrm{E}$ ratio and urine $(\mathrm{THF}+5 \alpha \mathrm{THF}) / \mathrm{THE}$ ratio, indicating 11ß-HSD 2 activity, are normalized in pediatric renal allograft recipients as compared with patients with chronic renal failure and a group of healthy children.

\section{Subjects and methods}

Fifty children were enrolled into the study. Fifteen patients (aged from 4.0 to 17.5 years) were suffering from chronic renal failure (CRF group), 17 patients (aged from 6.0 to 15.5 years) were pediatric renal allograft recipients (TX group) (time after TX from 0.5 to 10.0 years), and 18 children (aged from 6.0 to 16.5 years) served as normal controls (CO). This control group consisted of 10 female and 8 male individuals with normal arterial blood pressure and no relevant past medical history or medication. The patients' characteristics are shown in Table 1 . The antihypertensive drug therapy in patients from the CRF and TX groups consisted of one or more of the following: angiotensin converting enzyme (ACE)-blocking agents, betablocking agents, calcium channel-blocking agents and diuretics; in most of them a combination of different drugs was used. The immunosuppressive therapy was based on Ciclosporine A or Tacrolimus in combination with Mycophenolate-mofetil. No corticosteroids were applied at the time of examination. The therapeutical characteristics of the patients are shown in Table 2.

All clinical and auxological data were obtained during routine visits to the hospital between 0800 and $1000 \mathrm{~h}$. Details are shown in Table 1.
Plasma cortisol and cortisone were determined simultaneously using liquid chromatography tandem mass spectrometry, with atmospheric pressure chemical ionization in the positive ion mode, according to a modified method of Vogeser (22). One hundred microliters of the samples and calibrators were deproteinized with methanol/zinc sulfate $(50 \mathrm{~g} / \mathrm{l}, 1 / 1 \mathrm{v} / \mathrm{v})$. After centrifugation, the supernatants were applied to an online solid-phase extraction column with subsequent HPLC separation employing column switching (extraction column: Oasis HLB $2.1 \times 20$ mm, $15 \mu \mathrm{m}$ (Waters, Milford, MA, USA)). The samples were washed with $5 \%$ methanol and eluted in back-flush with $2 \mathrm{mmol} / \mathrm{l}$ ammonium acetate/methanol (30:70, v/v) onto the analytical column (Chromolith RP $18 \mathrm{e} 100 \times 4.6 \mathrm{~mm}$; Merck, Darmstadt, Germany) at a flow rate of $1 \mathrm{ml} / \mathrm{min}$. Sample analysis was performed in the multiple-reaction monitoring mode with a dwell time of $150 \mathrm{~ms}$ per channel using the following transitions for quantification (figures in brackets represent qualifier transition): $\mathrm{m} / \mathrm{z} 363.2 / 121.2(363.2 / 309.4)$ for cortisol, m/z 361.1/162.9 (361.1/239.0) for (cortisone, m/z $367.3 / 121.2$ for cortisol $(9,11,12,12-\mathrm{D} 4)$ internal standard $\left(\right.$ cortisol- $\left.\mathrm{d}_{4}\right)$. The intra-assay coefficients of variation were $2.6 \%-4.0 \%$ for cortisone (concentration range $19-38 \mathrm{ng} / \mathrm{ml}$ ) and $2.0 \%-5.6 \%$ for cortisol (concentration range $55-206 \mathrm{ng} / \mathrm{ml}$ ).

Urinary steroid profiles were measured by gas chromatography/mass spectrometry using the extraction technique described by Schmidt et al. (23). Briefly, THE, THF and $5 \alpha$ THF in urine $(2 \mathrm{ml})$ were extracted on C18 SPE columns (Machery-Nagel, Düren, Germany) and eluted in methanol $(2 \times 1.5 \mathrm{ml})$. The dried eluate was hydrolyzed with $\beta$-glucuronidase/arylsulfatase $\left(20 \mu \mathrm{l}, 3 \mathrm{~h}\right.$ at $58^{\circ} \mathrm{C}$; Roche, Penzberg, Germany) in sodium acetate buffer $(0.1 \mathrm{~mol} / \mathrm{l}, \mathrm{pH}=4.6)$. Following addition of the internal standards androstandiol, coprostane and cortisol- $\mathrm{d}_{4}$, and further purification over amino extraction columns, methyloxime-trimethylsilyl ether derivatives were made

Table 1 Characteristics of patients suffering from chronic renal failure (CRF), pediatric renal allograft recipients (TX) and healthy normal controls. Patient number, age, gender, body mass index (BMI), diagnoses, systolic and diastolic arterial blood pressure SDS are listed and are expressed as means \pm S.E.M. and range (age, BMI).

\begin{tabular}{|c|c|c|c|}
\hline & Group CRF & Group TX & Controls \\
\hline Number & 15 & 17 & 18 \\
\hline Age (years, range) & $15.1 \pm 4.1,4.0-17.5$ & $12.8 \pm 4.8,6.0-15.5$ & $12.9 \pm 5.0,6.0-16.5$ \\
\hline BMI (kg/m², range) & $21.9 \pm 5.2,19.1-26.8$ & $20.7 \pm 4.3,18.0-24.0$ & $21.8 \pm 5.6,15.5-25.8$ \\
\hline Diagnosis & $\begin{array}{l}\text { Membrano-proliferative } \\
\text { glomerulonephritis (1), } \\
\text { paracellin deficiency (1), } \\
\text { hemolytic uremic syndrome (3) } \\
\text { renal dysplasia (2), } \\
\text { nephrotic syndrome (end-stage } \\
\text { renal failure) (8) }\end{array}$ & $\begin{array}{l}\text { Nephrotic syndrome (6), } \\
\text { hemolytic uremic syndrome (2) } \\
\text { Prune-Belly syndrome (1), } \\
\text { Bardet-Biedl syndrome (2), } \\
\text { renal dysplasia (4), } \\
\text { nephronophtisis (1), } \\
\text { cystinosis (1) }\end{array}$ & None \\
\hline Systolic arterial blood pressure SDS & $0.26 \pm 0.33$ & $0.25 \pm 0.29$ & $0.37 \pm 0.30$ \\
\hline Diastolic arterial blood pressure SDS & $0.06 \pm 0.24$ & $0.04 \pm 0.28$ & $-0.07 \pm 0.36$ \\
\hline
\end{tabular}


Table 2 Therapeutical characteristics of patients suffering from chronic renal failure (CRF), pediatric renal allograft recipients (TX) and healthy normal controls. Time after allograft renal transplantation is listed and expressed as mean \pm S.E.M. and range.

\begin{tabular}{|c|c|c|c|}
\hline & Group CRF & Group TX & Controls \\
\hline Number & 15 & 17 & 18 \\
\hline Antihypertensive drugs & $\begin{array}{l}\text { ACE-blocking agents (12), beta-blocking } \\
\text { agents }(10) \text {, calcium-channel-blocking } \\
\text { agents (8), diuretics (3), no therapy (0) }\end{array}$ & $\begin{array}{l}\text { ACE-blocking agents (13), } \\
\text { beta-blocking agents (11), } \\
\text { Ca-channel-blocking agents(8), } \\
\text { diuretics (7), no therapy (2) }\end{array}$ & None \\
\hline \multirow{5}{*}{$\begin{array}{l}\text { Number of antihypertensive drugs } \\
\text { (number/patients) }\end{array}$} & $0 / 0$ & $0 / 2$ & None \\
\hline & $1 / 3$ & $1 / 4$ & \\
\hline & $2 / 6$ & $2 / 6$ & \\
\hline & $3 / 3$ & $3 / 4$ & \\
\hline & $4 / 3$ & $4 / 1$ & \\
\hline Immunsuppressive drugs & No therapy (15) & $\begin{array}{l}\text { Ciclosporin A (8), Tacrolimus (9), } \\
\text { Mycophenolate-mofetil } \\
\text { (17), Prednison (0), no therapy } \\
\text { (0) }\end{array}$ & None \\
\hline \multirow{2}{*}{$\begin{array}{l}\text { Time after renal allograft } \\
\text { transplantation (years, range) }\end{array}$} & None & $4.7 \pm 2.7$ & None \\
\hline & & $0.5-10.0$ & \\
\hline
\end{tabular}

using $2 \%$ methoxyamine hydrochloride in pyridine $\left(50 \mu \mathrm{l}, 1.5 \mathrm{~h}, 80^{\circ} \mathrm{C}\right)$ and $\mathrm{N}-$ methyl-N-trimethylsilyltrifluoracetamide (MSTFA)/1-trimethylsilylimidazole (TMCS)/trimethylchlorsilane (TMSIM) (1000/50/20, $\left.27 \mathrm{~h}, 100^{\circ} \mathrm{C}\right)$. These derivatives were then analyzed on a Shimadzu QP5050 gas chromatograph (Shimadzu, Kyoto, Japan) equipped with a mass selective detector. The gas chromatograph was fitted with a ZB- $5 \mathrm{~ms}$ column (30 $\mathrm{m} \times 0.25 \mathrm{~mm}$, film thickness $0.25 \mu \mathrm{m}$; Phenomenex, Terrance, CA, USA). Helium was used as the carrier gas under the following conditions: interface temperature $300^{\circ} \mathrm{C}$, oven temperature initially $218{ }^{\circ} \mathrm{C}$ for $3 \mathrm{~min}$ increasing at $2{ }^{\circ} \mathrm{C} / \mathrm{min}$ to $295^{\circ} \mathrm{C}$ for $7.5 \mathrm{~min}$. The following masses were selected for single ion monitoring (figures in brackets represent qualifier ions): $\mathrm{m} / \mathrm{z} 398.5$ (488.7, 578.7) THE, m/z 382.5 (652.7, 472.7, 562.7) THF and $5 \alpha$ THF. The interassay coefficients of variation of quality control samples $(n=13)$ were $10 \%$ for THE (mean concentration $2.86 \mu \mathrm{g} / \mathrm{ml}$ ), and $11 \%$ for $\mathrm{THF}$ (mean concentration $1.92 \mu \mathrm{g} / \mathrm{ml}$ ) and for $5 \alpha \mathrm{THF}$ (mean concentration $2.11 \mu \mathrm{g} / \mathrm{ml}$ ).

After centrifugation of blood samples, plasma and urine samples (collected over $24 \mathrm{~h}$ ) were kept frozen for up to 8 weeks at $20^{\circ} \mathrm{C}$ and were analyzed when all specimens had been obtained.

The activity of $11 \beta-H S D 2$ in plasma was calculated using the precursor/product ratio of $\mathrm{F} / \mathrm{E}$. The activity of $11 \beta-H S D 2$ in urine was calculated using the precursors/product ratio of $(\mathrm{THF}+5 \alpha \mathrm{THF}) / \mathrm{THE}$. The creatinine clearance $(\mathrm{CreaCl})$ was calculated according to the formula of Schwartz (24).

Values are shown as means \pm S.D./s.E.M., steroids with range [min, max]. All groups of data passed normality tests and showed a Gaussian distribution. Data with Gaussian distribution were correlated by linear regression. Parametric data were compared by twotailed $t$-test. In the case of multiple tests, data were compared using one-way ANOVA, and in the case of significance, a post-hoc $t$-test was used. $P$ values were corrected according to Bonferroni. A $P$ value $<0.05$ was considered statistically significant $(25,26)$.

The study was approved by the local ethics committee (Friedrich-Alexander-University Erlangen-Nürnberg). Informed consent was obtained from parents and, as far as possible, also from the children.

\section{Results}

There was no significant difference between plasma cortisol values within the three groups, whereas plasma cortisone levels were significantly lower in the CRF $(13.8 \pm 4.7 / 1.2[10.0,19.2] \mathrm{ng} / \mathrm{ml})$ and the TX groups $(10.9 \pm 6.2 / 1.6[6.6,16.8] \mathrm{ng} / \mathrm{ml})$ compared with healthy controls $(55.0 \pm 28.7 / 6.7[28.1,72.0] \mathrm{ng} / \mathrm{ml})$ $(P<0.0001)$. Plasma cortisone levels in the CRF and TX patients were not different. In the CRF group, we cal-

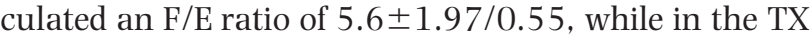
group $7.16 \pm 3.09 / 0.86$ was calculated. These values were significantly higher than in the control group (1.18 $\pm 0.15 / 0.03, \quad P<0.0001) \quad$ (Fig. 1). Urinary THF was not different between the three groups (CRF: 90.6 $\pm 48.8 / 13.0 \quad[52.5,124.5] \quad \mathrm{mg} / 24 \mathrm{~h}$; TX: 43.8 $\pm 48.19 / 12.0 \quad[15,45.1] \mathrm{mg} / 24 \mathrm{~h} ; \mathrm{CO}$ : $59.8 \pm 56.1 / 14.0[15,94] \mathrm{mg} / 24 \mathrm{~h})$ and neither was urinary 5 $\alpha \mathrm{THF}$ (CRF: $156.2 \pm 37.3 / 55.2$ [60.5, 165]

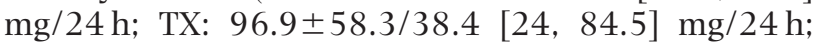
CO: $161.6 \pm 42.6 / 57.2[16.5,194] \mathrm{mg} / 24 \mathrm{~h})$. Urinary THE values were significantly lower in CRF $(178.4 \pm 16.9 / 29.6[88.5,251.5] \mathrm{mg} / 24 \mathrm{~h})$ and TX patients $(72.3 \pm 47.9 / 12.4[29.5,105.5] \mathrm{mg} / 24 \mathrm{~h})$ than in healthy subjects $(693.3 \pm 250 / 57.4[456,944]$ $\mathrm{mg} / 24 \mathrm{~h}, \mathrm{P}<0.0001)$. THE values were not different between $\mathrm{CRF}$ and $\mathrm{TX}$ patients. The ratio of $(\mathrm{THF}+5$ 

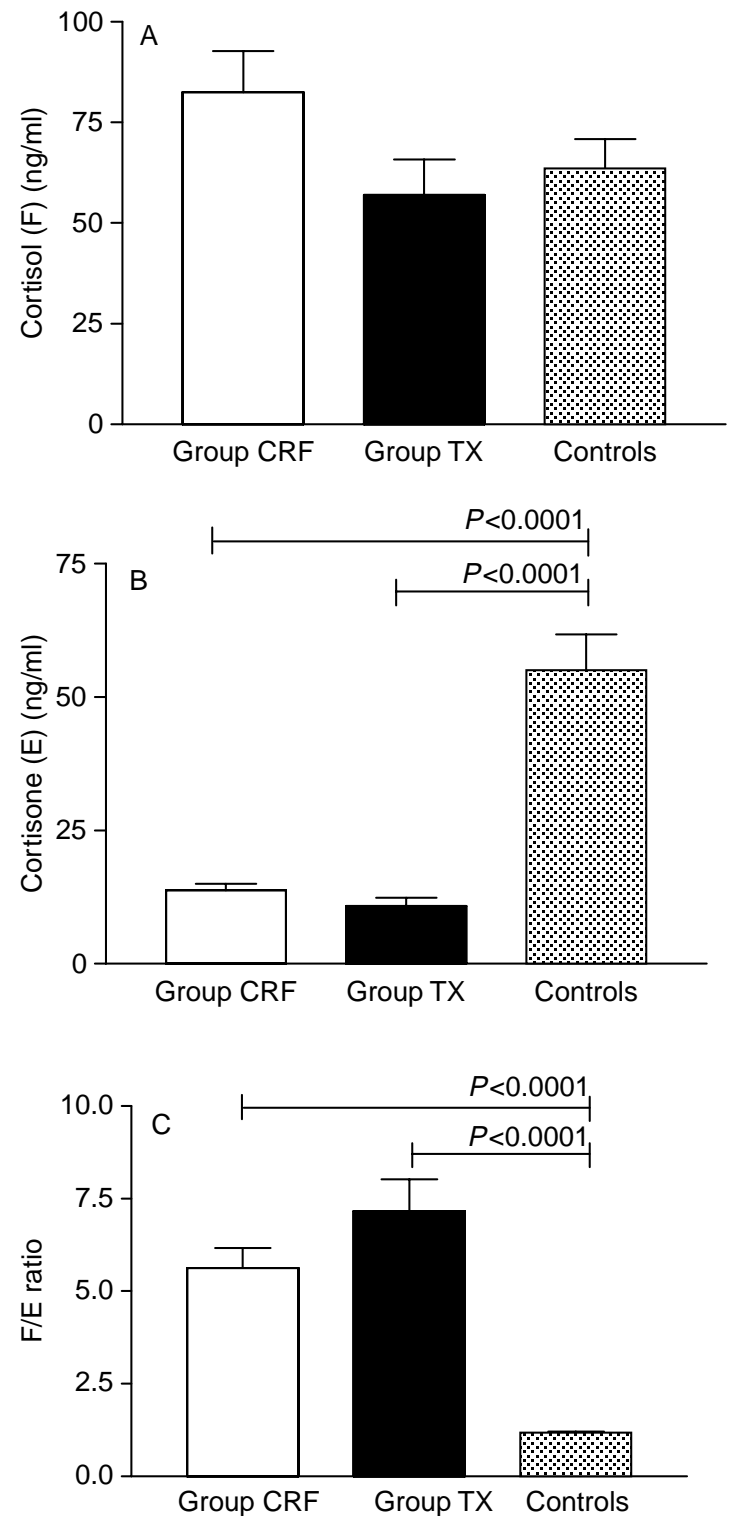

Figure 1 (A) Cortisol, (B) cortisone and (C) cortisol/cortisone ratio measured in plasma using tandem mass spectrometry in patients suffering from chronic renal failure (group CRF), pediatric renal allograft recipients (group TX) and controls. Data are shown as means \pm S.E.M. Significant differences between the study groups were evaluated using one-way ANOVA, $P$ values were corrected according to Bonferroni.

$\alpha \mathrm{THF}$ )/THE was significantly higher in the CRF group $(1.19 \pm 0.48 / 1.13)$ and TX group $(1.19 \pm 0.5 / 0.13)$ than in the control group $(0.21 \pm 0.18 / 0.05)$ $(P<0.0001)$, but the ratio was not different between CRF and TX patients (Fig. 2).

In two patients, urinary steroids before and after kidney transplantation were measured. In patient 1 , urinary THF was $45.5 \mathrm{mg} / 24 \mathrm{~h}$ before and $47.5 \mathrm{mg} / 24 \mathrm{~h}$ after transplantation, $5 \alpha \mathrm{THF}$ was
$97.2 \mathrm{mg} / 24 \mathrm{~h}$ before and $82.3 \mathrm{mg} / 24 \mathrm{~h}$ after transplantation, and THE was $85.3 \mathrm{mg} / 24 \mathrm{~h}$ before and $92.3 \mathrm{mg} / 24 \mathrm{~h}$ after transplantation; urinary $(\mathrm{THF}+5$ $\alpha \mathrm{THF}$ )/THE ratios of 1.67 before and 1.41 after kidney transplantation were calculated. In patient 2 , we found ratios of 1.32 before and 1.12 after kidney transplantation.

There were positive and highly significant correlations between plasma and urinary ratios in each group $\left(P=0.0004 . R^{2}=0.73\right.$ in the CRF group, $P=0.0013, \quad R^{2}=0.56$ in the TX group, and $\mathrm{P}<0.0001, \mathrm{R}^{2}=0.66$ in the CO group).

Neither systolic nor diastolic blood pressure standard deviation scores (SDS) (27) revealed any statistical differences when compared between the groups (Table 1). There was no significant correlation between blood pressure SDS and urinary (THF $+5 \alpha \mathrm{THF}$ )/THE or plasma F/E ratios (CRF group: $P=0.99, \mathrm{R}^{2}=0.000014$; Tx group: controls: $P=0.66, \mathrm{R}^{2}=0.01 ; P=0.69, \mathrm{R}^{2}=0.01$ ). There was no significant correlation between the number of antihypertensive drugs used and the $(\mathrm{THF}+5 \alpha \mathrm{THF}) / \mathrm{THE}$ ratio in the urine of CRF and TX patients $\left(P=0.56, \quad R^{2}=0.0 .27, \quad P=0.72\right.$, $\left.\mathrm{R}^{2}=0.0087\right)$. In the CRF group, CreaCl was $19.8 \pm 5.8 / 1.5 \mathrm{ml} / \mathrm{min} / 1.73 \mathrm{~m}^{2}$, significantly lower than in the TX group $\left(81.0 \pm 54.6 / 13.2 \mathrm{ml} / \mathrm{min} / 1.73 \mathrm{~m}^{2}\right)$, whereas CreaCl was normal in healthy controls $\left(177.7 \pm 67.7 / 17.5 \mathrm{ml} / \mathrm{min} / 1.73 \mathrm{~m}^{2}\right)$. No significant correlations between $\mathrm{CreaCl}$ and the urinary $(\mathrm{THF}+5$ $\alpha \mathrm{THF}) / \mathrm{THE}$ or plasma $\mathrm{F} / \mathrm{E}$ ratios were found in any group (CRF: $P=0.4, \quad \mathrm{R}^{2}=0.054 ; \quad \mathrm{TX}: \quad P=0.43$, $\mathrm{R}^{2}=0.0042$; CO: $P=0.62, \mathrm{R}^{2}=0.015$ ).

No significant correlations could be found between time after renal allograft transplantation and the correlated ratios in plasma and urine in the TX group $\left(P=0.53, R^{2}=0.027\right)$.

\section{Discussion}

Our data show significantly higher plasma F/E ratios in children with chronic renal failure (CRF group) and those with pediatric renal allografts (TX group). The urinary precursor/product ratio calculated as the $(\mathrm{THF}+5 \alpha \mathrm{THF}) / \mathrm{THE}$ ratio was substantially higher in CRF patients and equally high in TX patients. Our data suggest reduced $11 \beta-H S D 2$ activity, both in children with end-stage renal failure and in patients after renal transplantation having steroid-free immunosuppressive therapy. For CRF children, these results are in line with those from other groups demonstrating reduced activity of $11 \beta-\mathrm{HSD} 2$ in adults with chronic renal failure $(6,28,29)$.

There was no difference in the cortisol/cortisone ratios between patients suffering from chronic renal failure and the pediatric renal allograft recipients in this study. In our opinion, these data demonstrate that the allograft transplantation of a donor kidney, 

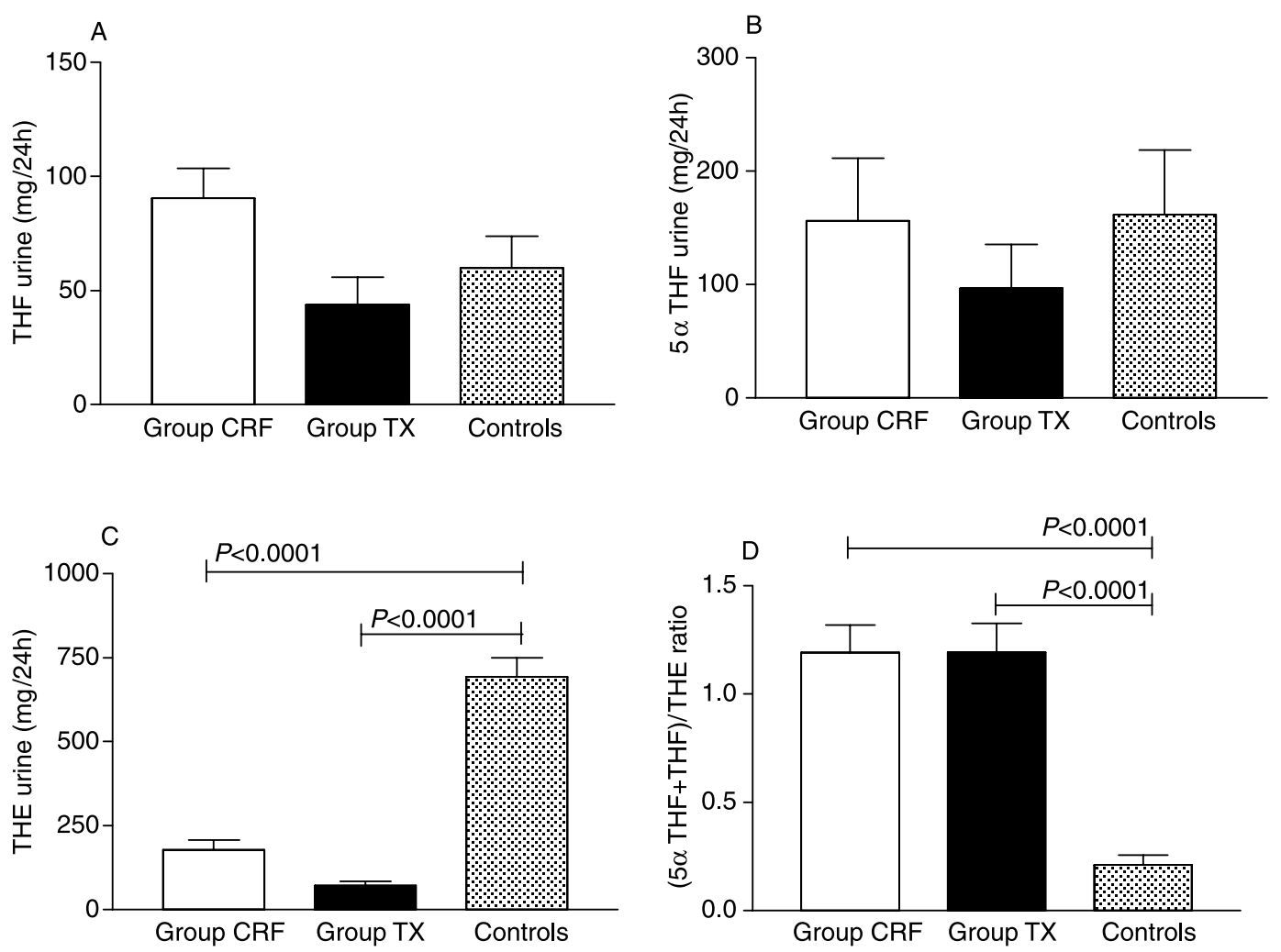

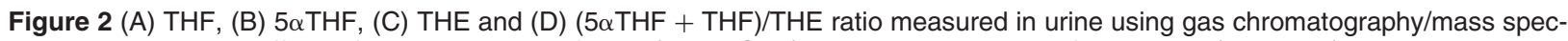
trometry in patients suffering from chronic renal failure (group CRF), pediatric renal allograft recipients (group TX) and controls. Data are shown as means \pm S.E.M. Significant differences between the study groups were evaluated using one-way ANOVA, $P$ values were corrected according to Bonferroni.

an organ that is thought to be mostly responsible for the regulation of the cortisol/cortisone shuttle by

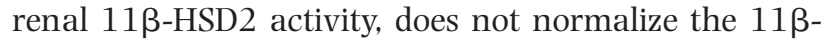
HSD2 activity. There is only one case report of normal $11 \beta-H S D 2$ activity after renal transplantation in a patient with AME (15). In this case, cortisol remained unconverted and was able to bind and activate the mineralocorticoid receptor leading to AME. The failure could, at least partially, be compensated by kidney transplantation. However, in contrast to our patients, this patient had a complete absence of $11 \beta-H S D 2$ before renal transplantation. Although 11ß-HSD2 appears to be reduced in CRF, its activity is much higher than in AME. Therefore, some restoration is to be expected after renal transplantation for AME.

The steroids data of two patients before and after renal transplantation showed that cortisol/cortisone ratios did not change considerably before and after renal transplantation. The number of examined patients in this study is relatively low. However, the number of pediatric transplant patients is also low: the total number of pediatric renal allograft transplantations in Germany is about 100/year.

Increased blood pressure, a frequent problem after renal allograft transplantation, is partially attributed to chronic allograft failure and immunosuppression $(16,18-20,30)$. Our data show that the failure to restore $11 \beta-H S D 2$ activity might also contribute to arterial hypertension. Furthermore, we have shown that neither urinary nor plasma F/E ratios are influenced by the level of chronic renal failure, as indicated by creatinine clearance, or by the age of the transplanted kidney. Therefore, we postulate that $11 \beta$ HSD2 cannot be restored to normal values by renal transplantation. The reduced activity of $11 \beta-H S D 2$ leads to an increase in various metabolites inducing salt retention and leading to arterial hypertension (3, $5,6,9,10,13,29,31,32)$. A very strict and aggressive antihypertensive drug therapy is necessary to avoid secondary complications of long-lasting arterial hypertension $(12,21,33-35)$. In all our TX and CRF children there was the necessity to apply antihypertensive drugs using a variable combination of ACE-, beta-, calcium-channel-blocking and diuretic drugs. Systolic and diastolic blood pressure SDS values were normalized, not revealing any differences compared with healthy controls. This might be an explanation for the fact that we could not find any correlation between blood pressure values and plasma or urinary $\mathrm{F} / \mathrm{E}$ ratios representing 11ß-HSD2 activity. The number of 
antihypertensive drugs per patient did not correlate with the activity of $11 \beta-H S D 2$. Possibly, the number of conflicting mechanisms does not allow for a simple relationship to be drawn between 11ß-HSD2 and blood pressure. Different medications such as diuretic drugs (e.g. furosemide) probably modulate urinary $11 \beta$-HSD2 activity and this could be the subject of further investigations. Impaired liver function or cholestasis might modulate $11 \beta-H S D 2$ activity. None of the children examined in our study showed hepatic insufficiency or cholestasis.

The measurement of cortisol and cortisone metabolites in urine is an estimate of the activity of human $11 \beta$-HSD in vivo $(6,36)$. The ratios reflect the activities of $11 \beta$-HSD 2 and $11 \beta$-HSD type 1 enzymes in various organs such as kidney, colon, skin, salivary glands and lung. The positive correlation between plasma and urinary ratios in our study shows the suitability of either plasma or urine to estimate $11 \beta$-HSD activity. However, ratios of cortisol/cortisone are not an exact parameter for $11 \beta-H S D$ activity, and therefore direct measurements of renal 11ß-HSD2 expression might be helpful to determine the role of this enzyme more precisely.

Palermo and co-workers (15) suppressed endogenous cortisol secretion using methyl prednisolone, dexamethasone, cortisol or cortisone, and this procedure could provide a possible method to detect the ability of patients to metabolize cortisol. Unfortunately, in a pediatric cohort of patients such additional examinations for academic reasons only are difficult to countenance on ethical grounds.

In summary, all our patients presenting with chronic renal failure have increased cortisol/cortisone ratios potentially reflecting reduced 11ß-HSD2 activity which could not be normalized by renal allograft transplantation. Normalization of systemic arterial blood pressure and clinically relevant changes in the creatinine clearance did not influence the cortisol/cortisone ratio. Reduced cortisol clearance by $11 \beta-H S D 2$ might contribute to the development of arterial hypertension after renal allograft transplantation.

\section{References}

1 Agarwal AK, Rogerson FM, Mune T \& White PC. Gene structure and chromosomal localization of the human HSD11K gene encoding the kidney (type 2) isozyme of 11beta-hydroxysteroid dehydrogenase. Genomics 199529 195-199.

2 Stewart PM, Whorwood CB \& Mason JI. Type 2 11beta-hydroxysteroid dehydrogenase in foetal and adult life. Journal of Steroid Biochemistry and Molecular Biology 199555 465-471.

3 Mune T, Rogerson FM, Nikkila H, Agarwal AK \& White PC. Human hypertension caused by mutations in the kidney isozyme of 11 beta hydroxysteroid dehydrogenase. Nature Genetics 1995 $10394-399$.

4 Suzuki T, Sasano H, Suzuki S, Hirasawa G, Takeyama J, Muramatsu Y, Date F, Nagura H \& Krozowski ZS. 11Betahydroxysteroid dehydrogenase type 2 in human lung: possible regulator of mineralocorticoid action. Journal of Clinical Endocrinology and Metabolism $1998 \mathbf{8 3} 4022-4025$.

5 N'Gankam V, Uehlinger D, Dick B, Frey BM \& Frey FJ. Increased cortisol metabolites and reduced activity of 11 beta-hydroxysteroid dehydrogenase in patients on hemodialysis. Kidney International 200261 1859-1866.

6 Palermo M, Shackleton CH, Mantero F \& Stewart PM. Urinary free cortisone and the assessment of 11beta-hydroxysteroid dehydrogenase activity in man. Clinical Endocrinology 199645 605-611.

7 Lakshmi V \& Monder C. Purification and characterization of the corticosteroid 11beta-dehydrogenase component of the rat liver 11 beta-hydroxysteroid dehydrogenase complex. Endocrinology 1988123 2390-2398.

8 Dotsch J, Hohenberger I, Peter M, Sippell W \& Dorr HG. Evidence for change of 11 beta-hydroxysteroid dehydrogenase activity during infancy and childhood. Paediatric Research $2000 \mathbf{4 8}$ $697-700$.

9 Ferrari P, Bianchetti M \& Frey FJ. Juvenile hypertension, the role of genetically altered steroid metabolism. Hormone Research 2001 $55213-223$.

10 Cerame BI \& New MI. Hormonal hypertension in children: 11 beta hydroxylase deficiency and apparent mineralocorticoid excess. Journal of Pediatric Endocrinology and Metabolism 200013 1537-1547.

11 Krozowski ZS, Stewart PM, Obeyesekere VR, Li K \& Ferrari P. Mutations in the 11beta-hydroxysteroid dehydrogenase type II enzyme associated with hypertension and possibly stillbirth. Clinical and Experimental Hypertension 199719 519-529.

12 Soergel M, Kirschstein M, Busch C, Danne T, Gellermann J, Holl R, Krull F, Reichert H, Reusz GS \& Rascher W. Oscillometric twentyfour-hour ambulatory blood pressure values in healthy children and adolescents: a multicenter trial including 1141 subjects. Journal of Pediatrics $1997130178-184$.

13 Watson B Jr. Genetics of the kidney and hypertension. Current Hypertension Reports 20035 273-276.

14 Aziz N, Maxwell MM \& Brenner BM. Coordinate regulation of 11beta-HSD and Ke 6 genes in cpk mouse: implications for steroid metabolic defect in PKD. American Journal of Physiology 1994267 F791-F797.

15 Palermo M, Delitala G, Sorba G, Cossu M, Satta R, Tedde R, Pala A \& Shackleton CH. Does kidney transplantation normalise cortisol metabolism in apparent mineralocorticoid excess syndrome? Journal of Endocrinological Investigation 200023 457-462.

16 Fontana I, Verrina E, Basile G, Arcuri V, Pellicci R, Tommasi GV, Perfumo F, Gusmano R \& Valente U. Arterial hypertension in the transplanted child: frequency and analysis of the causes. Transplant Procedures 199426 79-80.

17 Nagasako SS, Koch Nogueira PC, Machado PG \& Medina Pestana JO. Arterial hypertension following renal transplantation in children - a short-term study. Pediatric Nephrology 200318 1270-1274.

18 Buscher R, Vester U, Wingen AM \& Hoyer PF. Pathomechanisms and the diagnosis of arterial hypertension in pediatric renal allograft recipients. Pediatric Nephrology 200419 1202-1211.

19 Curtis JJ. Cyclosporine and posttransplant hypertension. Journal of the American Society of Nephrology 19922 S243-S245.

20 Jungraithmayr T, Staskewitz A, Kirste G, Boswald M, Bulla M, Burghard R, Dippell J, Greiner C, Helmchen U, Klare B, Klaus G, Leichter HE, Mihatsch MJ, Michalk DV, Misselwitz J, Plank C, Querfeld U, Weber LT, Wiesel M, Tonshoff B \& Zimmerhackl LB. Pediatric renal transplantation with mycophenolate mofetilbased immunosuppression without induction: results after three years. Transplantation $2003 \mathbf{7 5}$ 454-461.

21 Lingens N, Dobos E, Lemmer B \& Scharer K. Nocturnal blood pressure elevation in transplanted pediatric patients. Kidney International Supplement 199655 S175-S176.

22 Vogeser M, Briegel J \& Jacob K. Determination of serum cortisol by isotope-dilution liquid-chromatography electrospray ionization tandem mass spectrometry with on-line extraction. Clinical Chemistry and Laboratory Medicine 200139 944-947. 
23 Schmidt NA, Borburgh HJ, Penders TJ \& Weykamp CW. Steroid profiling - an update. Clinical Chemistry 198531 637-639.

24 Stejskal J, Novakova J \& Reitschlagrova V. Validity of routinely used methods of testing glomerular filtration in pediatric practice. Ceskoslovenska Pediatrie $199045662-666$.

25 O'Brien PC \& Shampo MA. Statistical considerations for performing multiple tests in a single experiment. 5. Comparing two therapies with respect to several endpoints. Mayo Clinic Proceedings $1988631140-1143$.

26 O'Brien PC \& Shampo MA. Statistical considerations for performing multiple tests in a single experiment. 6. Testing accumulating data repeatedly over time. Mayo Clinic Proceedings 198863 1245-1250.

27 de Man SA, Andre JL, Bachmann H, Grobbee DE, Ibsen KK, Laaser U, Lippert P \& Hofman A. Blood pressure in childhood: pooled findings of six European studies. Journal of Hypertension $19919109-114$.

28 Phillipov G. Effect of hypercortisolism and ACTH on the metabolism of cortisol. Experimental and Clinical Endocrinology and Diabetes $1998 \mathbf{1 0 6} 57-60$.

29 Stewart PM, Krozowski ZS, Gupta A, Milford DV, Howie AJ, Sheppard MC \& Whorwood CB. Hypertension in the syndrome of apparent mineralocorticoid excess due to mutation of the 11 beta-hydroxysteroid dehydrogenase type 2 gene. Lancet 1996 347 88-91.

30 Basset el EA, Berthoux P, Cecillon S, Deprle C, Thibaudin D, De Filippis JP, Alamartin E \& Berthou F. Hypertension after renal transplantation and polymorphism of genes involved in essential hypertension: ACE, AGT, AT1 R and ecNOS. Clinical Nephrology $200257192-200$.

31 Csabi GY, Juricskay S \& Molnar D. Urinary cortisol to cortisone metabolites in hypertensive obese children. Journal of Endocrinological Investigation $2000 \mathbf{2 3}$ 435-439.
32 Gourmelen M, Saint-Jacques I, Morineau G, Soliman H, Julien R \& Fiet J. 11Beta-hydroxysteroid dehydrogenase deficit: a rare cause of arterial hypertension. Diagnosis and therapeutic approach in two young brothers. European Journal of Endocrinology 1996 $135238-244$.

33 Schroth M, Kratzsch J, Groschl M, Rauh M, Rascher W \& Dotsch J. Increased soluble leptin receptor in children with nephrotic syndrome. Journal of Clinical Endocrinology and Metabolism $2003 \mathbf{8 8}$ 5497-5501.

34 Jungraithmayr T, Staskewitz A, Kirste G, Boswald M, Bulla M, Burghard R, Dippell J, Greiner C, Helmchen U, Klare B, Klaus G, Leichter HE, Misselwitz J, Platzer L, Ouerfeld U, Rascher W, Tonshoff B, Wiesel M, Brandis M \& Zimmerhackl LB. Prevalence of arterial hypertension and its morbidity in children and adolescents 3 years after renal transplantation with mycophenolate mofetil-based immunosuppression. Transplant Procedures 2002 342215.

35 Wuhl E, Witte K, Soergel M, Mehls O, Schaefer F, Kirschstein M, Busch C, Danne T, Gellermann J, Holl R, Krull F, Reichert H, Reusz GS \& Rascher W. Distribution of 24-h ambulatory blood pressure in children: normalized reference values and role of body dimensions. Journal of Hypertension 200220 1995-2007.

36 Palermo M, Delitala G, Mantero F, Stewart PM \& Shackleton CH. Congenital deficiency of 11 beta-hydroxysteroid dehydrogenase (apparent mineralocorticoid excess syndrome): diagnostic value of urinary free cortisol and cortisone. Journal of Endocrinological Investigation $2001 \mathbf{2 4} 17-23$.

Received 1 November 2005

Accepted 13 January 2006 